\title{
Design of College Students' employment management system based on WEB
}

\author{
Yu CAO ${ }^{1, a}$ \\ ${ }^{1}$ Jiangxi Science \& Technology Normal University, Nanchang, Jiangxi, 330013, P.R. China
}

\begin{abstract}
Since at the end of last century, our country cancelled the allocation of national college students employment, college graduates employment pressure also with the increasing trend of the expansion of enrollment in Colleges and universities. At the same time, it also greatly increased difficulty in the college students employment management, under this background, the traditional manual management mode obviously can not meet the required at present. In the information technology increasingly perfect today, how it has become an important task of university reform through the digital management information system technology research and development of College Students' employment. In this paper, a management system based on Web Technology College Students Employment launches the analysis, aimed at through the information technology, to promote the management of information, efficient development, so as to provide an important reference for the employment decision.
\end{abstract}

Key words: Employment guidance; employment management; WEB; system design

\section{Introduction}

Based on the employment management system of modern information technology can timely query of college students employment whereabouts, unit of invite applications for a job related information, students' personal information and through this system to student's employment status were tracking and evaluation, and according to the evaluation results clear talent cultivation mode is there problems, to provide the direction of reform, so as to promote college students' employment ability, promote employment rate [1]. Following on a management system based on Web Technology College Students Employment launches the analysis, aimed at through this kind of management system, contributing to the management of information, efficient development, provide the basis for the employment decision, as follows.

\section{The significance of the construction of College Students' employment management system based on WEB}

University leadership needs to grasp the current employment trends and employment of students, which is also an important indicator of the strength of teaching in Colleges and universities [2]. In addition, many areas of education departments are required local colleges and universities on a regular basis to the employment situation statistics reported, including the signing of the

\footnotetext{
${ }^{\mathrm{a}}$ Corresponding author: 466167034@qq.com
}

number of posts, employment intentions, etc.. Therefore, it is necessary to take effective statistics and analysis means to ensure the timeliness and accuracy of employment. From the perspective of colleges and universities, the employment management system can make scientific statistics on the employment situation of students, and make clear the students' employment intention, so as to provide valuable reference for employment guidance. From the perspective of students, students can also be employed by the employment management system for the use of the unit to query, twoway selection [3], but also more conducive to helping students to carry out career planning.

\section{Design of College Students' employment management system based on WEB}

\subsection{System structure design}

Based on Web employment management system main interface and back office interface, which interface is mainly the employment department staff on the current college students employment information management and related operations, the interface of the B / S structure, to ASP. Net on the web server site to interact. This design can fully realized by WWW browser to login the system, so as to realize the structure of the employment management based on the web, which greatly facilitate 
the system [4]. The backstage interface plays to the information data statistics, the analysis function, in which the database is the core of the system. System database management system selects Microsoft SQL Server 2005, SQL Server Management Studio to create a database. A database and on the create including employment survey, user information, professional information, employment analysis a number of functional components. The SQL Server2005 a completely able to achieve web products, teachers can through the system access, edit, publish employment information, students can in this system of employment information release and checking operation. And the management and maintenance of the system is performed by the system administrator, as figure 1 .

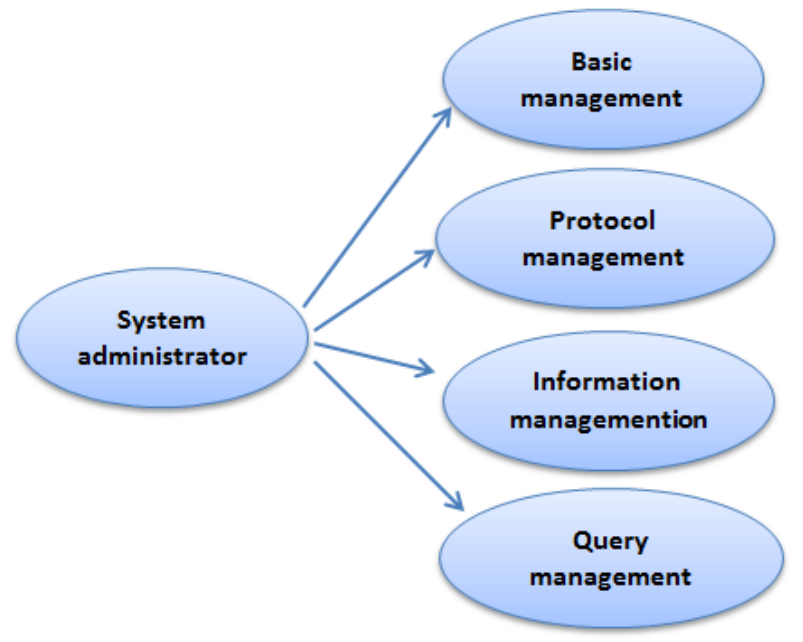

Figure 1. System administrator permissions diagram in the system functions

\subsection{Functional module design of the system}

System mainly includes the following function modules: user registration module, employment information management and employment guidance module and management module of the unit, the employment department management module, statistical module of employment, employment information query module, the employment agreement and policy management module and turnover and default function module etc.

\subsubsection{User registration module}

WEB based employment management system design for membership registration system, set by the system administrator privileges. There is no registered user that is a tourist, available information is limited. By the system administrators to different users of the rights to set [5], such as the students registered users can be information query, download, and employment guidance module in the interactive features. The teacher user can be registered on the basis of user rights, to achieve employment information editing, upload, modify, and other functions. User information can be released by the user, or according to the needs of the user, the system recommended by the system to meet the conditions of College students.

\subsubsection{College students employment information management and employment guidance module}

Each university student users in this module has a resume template, the student user login, you can edit your resume, you can download the resume template [6]. Students can also fill in their employment information management module in the employment information management module, the employment guidance module can be based on the students' employment intentions of screening results, to provide students with relevant employment information.

\subsubsection{Unit management module}

Employing units to provide relevant information to the University and registered in the system, after the audit, as a member of the employing unit. The employer to publishing in the module units have confidence, at the same time, the system also can according to unit needs and recommend to meet the requirements of the students resume, college employment personnel can also be according to the requirements of the enterprise employment, to unit of choose and employ persons recommended interview and interview results to release in the employing unit management module.

\subsubsection{College employment department management module}

Department of employment management in Colleges and universities is required to release the college students' employment related information in the system, employment sector managers not only from colleges and universities employment sector also includes various department of employment guidance teachers, in addition to the dissemination of relevant information, these personnel also responsible for employment management information system in the information audit and authenticity of the investigation.

\subsubsection{Employment statistics module}

This module is a module for the statistics and analysis of the employment situation, job position, salary and employment rate of college students. In addition, this module also has the print function, teacher users and system administrators can be directly retrieved and printed.

\subsubsection{Employment information inquiry module}

This module, whether teachers, students, students, or users, can be used to enter the key words, the search to the relevant information available to the public

\subsubsection{Employment agreement and policy management module}

Graduate students in the process of job search and recruitment, the university can check the employment 
agreement through this system module, so as to determine whether the student employment. In addition, the system will be based on the needs of the enterprise, the first time to inform students of the formal appointment of the money needed to do the preparation, the student after induction, the need to record in the system.

\subsubsection{Turnover and default function module}

College students in the employment process, there may be job hopping problem, there are some students after the signing of the entry agreement, may be due to the existence of one's own or other factors. Therefore in order to be employment management system more complete and need to set turnover and default module, in which recording their employment after the breach and turnover, and clearly is unit reason is their own reasons. Can also provide opportunities for students to a two-way choice, if an employer reason for the unit often students leaving the problem, based on for students to develop perfect employment planning principles, the need to remind students to avoid such enterprises signed.

\section{Conclusion}

To sum up, this paper first based on web of college students employment management system construction significance analysis. After the structure design of the system are discussed, finally, respectively, from the user registration module, employment information management and employment guidance module and management module of the unit, the employment department management module, statistical module of employment, employment information query module, the employment agreement and policy management module and turnover and default function module of system function design are analyzed and hope that this research can provide some reference for the stakeholders.

This paper is the Research Institute of Vocational Education in Jiangxi science and technology Normal University and the research on the effectiveness of the teaching effectiveness of Jiangxi Province Education Science Planning Project (NO:15YB084).

\section{References}

1. Xu Jingcai. Web based medical students' career planning of CAI multimedia courseware design [J]. Journal of electronic design engineering, 2015, 14:173-175.

2. Metcalf jv, li yu, Chen Lijun NiuLei. College student dormitory management system based on Web design and implementation of $[\mathrm{J}]$. Computer knowledge and technology, 2014:8098-8100.

3. Shun, Liang Guicai Li Jiguo, Liu Ming. Based on Asp.net/.Net Web Service report of higher vocational college graduates employment information management system [J]. The design and implementation of enterprise and the development of science and technology, 2011 preceding: 19-21.
4. Lu Hongcai. Student employment management system based on WEB - in the design and implementation of industrial vocational and technical college as an example in gansu province [J]. Journal of nanyang institute of technology, 2011, 2011:24-27.

5. Li Yang ling. Based on field work and employment outside the WEB research and implementation of quality control management system [J]. Journal of information and computer (theory), cutflower production potentials of 2014:132-133.

6. Garrel Dr. Based on WEB3.0 technology vocational school graduates employment tracking system, the design and implementation of higher vocational and technical school in suzhou as an example [J]. Journal of digital technology and application, 2013 cutflower production potentials: + 119 116-117. 